\title{
Honey Mead Fermentation from Thai Stingless Bee (Tetragonula leaviceps) Honey using Ethanol Tolerant Yeast
}

\author{
Pimprapa Chaijak ${ }^{1,2^{*}}$, Purimprach Sinkan ${ }^{1}$, Santipap Sotha ${ }^{1}$ \\ 1 Microbial Fuel Cell \& Bioremediation Laboratory, \\ Faculty of Science, Thaksin University, Phatthalung, Thailand \\ 2 Microbial Technology for Agriculture, Food and Environment \\ Research Center, Thaksin University, Phatthalung, Thailand \\ *corresponding author: chaijak.pimprapa@gmail.com
}

\begin{abstract}
Honey mead is a well-known conventional alcoholic beverage made by microbial fermentation of diluted honey. The selection of prospective yeasts for inoculation of honey-must with regard to honey mead quality determines the quality of mead production. The yeast consortium tolerant to ethanol stress was selected for this study using an enrichment technique. The activity of the invertase enzyme and the level of ethanol tolerance have been investigated. Thai stingless bee honey was used as a substrate, and the selected ethanol tolerant yeast consortium was used for mead fermentation. The results revealed that the PP03 had the highest invertase activity of $75.13 \pm 9.16 \mathrm{U} / \mathrm{mL}$ and the highest ethanol tolerance level of $12 \%$. This is the first study using an ethanol tolerant yeast consortium to
\end{abstract} ferment honey mead from Thai stingless bee honey.

Keywords: stingless bee, honey wine, mead, ethanol tolerant yeasts, fermented food, beverage

\section{Introduction}

Beverages have played an important role in human history in terms of improving food nutrition and food preservation (Shiby and Misha, 2013). Alcoholic beverages and their non-alcoholic equivalents include beers, wine, spirits, cider, mead, sake, and others (Makwana and Hati, 2019; Hornsey, 2007). Alcoholic beverages are mostly made from saccharide ingredients, such as mead from honey, beer from grain, wine from fruit, and sake from rice (Hornsey, 2007). Equation (1) depicts the conversion of sugar (glucose) to alcohol (ethanol), which typically takes 2-4 weeks at $20-30{ }^{\circ} \mathrm{C}$ (Walker and Stewart, 2016).

$$
\mathrm{C}_{6} \mathrm{H}_{12} \mathrm{O}_{6} \rightarrow 2 \mathrm{C}_{2} \mathrm{H}_{6} \mathrm{O}+2 \mathrm{CO}_{2}
$$

Honey mead, also known as honey wine, is a favourite alcoholic drink made from bee honey, water, herbs (clove, cinnamon, nutmeg, oregano, chamomile, and lavender), and some fruit (blackberry, strawberry, and raspberry)
(Gupta and Sharma, 2009). Honey mead fermentation consists of two major stages: (1) fermentation at $15-25^{\circ} \mathrm{C}$ for 3-6 weeks and (2) aging in oak barrels at $10-15^{\circ} \mathrm{C}$ for up to 10 years (de Simon et al., 2014). This beverage has received positive feedback in terms of human health, such as a lower risk of heart disease, diabetes, and stroke (Chang et al., 2016).

The stingless bee (Tetragonula leaviceps) is a highly domesticated bee found in tropical and subtropical territories such as Thailand (Suntiparapop et al., 2011; Jame, 2004). The stingless bee collects the plant sugar solution and converts it into bee honey through bee hypopharyngeal gland enzymes such as diastase, amylase (EC 1.2.1.1), glucosidase (EC 3.2.1.20) and glucose oxidase (EC 1.1.3.). Diastase and amylase catalyses starch breakdown into shorter carbohydrate chains or maltose while glucosidase transform sucrose into glucose and fructose. Glucose oxidase is responsible for antimicrobial activity due to the 
oxidation of glucose to hydrogen peroxide or D-gluconolactones (Edelhauser and Bergner, 1987). Stingless bee honey is composed of $80-85 \%$ of carbohydrates (46-72\% of glucose, $7-61 \%$ of fructose, and $1-11 \%$ of sucrose), $15-17 \%$ of water, $0.3 \%$ of proteins (arginine, histidine, isoleucine, lysine, methionine, threonine, tryptophan, valine and other amines), and $0.2 \%$ of ash. Furthermore, Thai stingless bee honey also contains vitamins B1, B6, and niacin. It has been consumed in the form of raw honey (Lim et al., 2018; Sawatthum et al., 2009; De Groot, 1953).

During ethanol fermentation, a great increase in the ethanol concentration ranging between 23.7 and $94.7 \mathrm{~g} / \mathrm{L}$ limits yeast growth rate and rate of ethanol production by 5.2 times. However, ethanol tolerant yeasts can improve the efficiency of fermentation under ethanol stress (Nguyen et al., 2015). The ethanol tolerant yeast has been found in a variety of sugar-rich materials, including fruit, distillery effluent, and molasses (Tikka et al., 2013). It has been reported to be used in the fermentation of rice wine (Flor and Hayashida, 1983), grape wine (Sumby et al., 2019), and pineapple wine (Tyokusa and Owuama, 2018). The goal of this research is to find an ethanol tolerant yeast consortium for use in the production of honey mead from stingless bee honey. This is the first research on using Thai stingless bee honey as a raw material for honey mead production.

\section{Material and Methods}

\subsection{Culture source}

Traditional culture starter balls composed of spontaneous mixed culture (Look-Pang) and fresh pineapple fruits were gathered from Thailand's various provinces. Fresh pineapples were carefully washed in sterile tap water to remove impurities. The peels of pineapple were separated and used as a culture source. Table 1 shows the specifics of the material type and location.
$10 \%(\mathrm{w} / \mathrm{v})$ of material used as the potential source of required yeast consortium (Table 1) was added into $200 \mathrm{~mL}$ of sterile liquid media, $\mathrm{pH} 7.0$ containing $10 \%$ $(\mathrm{w} / \mathrm{v})$ sucrose, and $0.1 \%(\mathrm{w} / \mathrm{v})$ Brewer's yeast extract (Cooray et al., 2017). The 10 samples containing materials stated in Table 1 were incubated at $30^{\circ} \mathrm{C}$ for 3 days without shaking in triplicate.

\subsection{Selection of Ethanol Tolerant Consortium}

Ethanol tolerant yeast was selected by inoculating $1 \mathrm{~mL}$ of previously obtained culture $\left(1.0 \times 10^{8}\right.$ cell $\left./ \mathrm{mL}\right)$ into $9 \mathrm{~mL}$ of sterile liquid media composed of $10 \%(\mathrm{w} / \mathrm{v}) \mathrm{su}-$ crose, $0.1 \%(\mathrm{w} / \mathrm{v})$ Brewer's yeast extract, and 5\% (v/v) food-grade ethanol and with $\mathrm{pH} 7$, then incubating it at $30{ }^{\circ} \mathrm{C}$ for 3 days. The original spontaneous culture was re-inoculated seven times to ensure that only an ethanol tolerant culture could be obtained. A suitable consortium of ethanol-producing yeasts was chosen.

\subsection{Determination of Invertase Activity}

The selected yeast consortia were grown in sterile liquid media containing $10 \%(\mathrm{w} / \mathrm{v})$ sucrose, $0.1 \%(\mathrm{w} / \mathrm{v})$ Brewer's yeast extract, and $5 \%(\mathrm{v} / \mathrm{v})$ food-grade ethanol with $\mathrm{pH} 7$ for three days at $30^{\circ} \mathrm{C}$. The invertase activity was determined using modified method according to Jimenez and Benitez (1986). In brief, $1 \mathrm{~mL}$ of cell solution was mixed with $2 \mathrm{~mL}$ of $4 \%(\mathrm{w} / \mathrm{v})$ sucrose in acetate buffer, $\mathrm{pH} 5$. All samples were incubated for 5 minutes at $30^{\circ} \mathrm{C}$. A commercial wine yeasts Saccharomyces cerevisiae Davis904 was used as a control. The dinitro-salicylic acid method was used to calculate the amount of reducing sugar released. Invertase activity was expressed in international enzyme unit defined as the amount of enzyme that catalyses a conversion of 1 mole of reducing sugar per minute. Invertase activity and ethanol content were measured every 12 hours for three days. The consortium with the highest invertase activity and ethanol yield was chosen.

Table 1 Details of material collection used as a source of ethanol tolerant yeast consortium

\begin{tabular}{|l|c|c|c|}
\hline Sample Type & Location & Collection Date & April, 2021 \\
\hline Sriracha pineapple & Chon Buri, Thailand & April, 2021 & PP01 \\
\hline Srithong pineapple & Trat, Thailand & April, 2021 & PP02 \\
\hline Wild pineapple & Phang Nga, Thailand & April, 2021 & Ppo3 \\
\hline Wild pineapple & Trang, Thailand 2021 & April, 2021 \\
\hline Wild pineapple & Chumphon, Thailand & April, 2021 & PP05 \\
\hline Culture starter balls & Surat Thani, Thailand & April, 2021 & LP01 \\
\hline Culture starter balls & Nakhonsi Thammarat, Thailand & April, 2021 & LP03 \\
\hline Culture starter balls & Phatthalung, Thailand & April, 2021 & LP04 \\
\hline Culture starter balls & Phang Nga, Thailand & LP05 \\
\hline Culture starter balls & Narathiwat, Thailand & & \\
\hline
\end{tabular}




\subsection{Determination of Ethanol Tolerance}

Ethanol tolerance of a selected consortium was investigated by allowing the consortium to grow in sterile liquid media containing $10 \%(\mathrm{w} / \mathrm{v})$ sucrose and $0.1 \%(\mathrm{w} / \mathrm{v})$ Brewer's yeast extract with varying concentrations of food-grade ethanol such as $0 \%, 3 \%, 6 \%, 9 \%, 12 \%$, and $15 \%(\mathrm{v} / \mathrm{v})$ took over from Tikka et al. (2013) and modified. The $10 \%(\mathrm{v} / \mathrm{v})$ culture $\left(1.0 \times 10^{8} \mathrm{cell} / \mathrm{mL}\right)$ was mixed with $90 \%(\mathrm{v} / \mathrm{v})$ liquid medium and incubated at $30^{\circ} \mathrm{C}$ for 3 days. At $24 \mathrm{hrs}$ of growth, the optical density at $600 \mathrm{~nm}$ (OD600) was measured.

\subsection{Honey Mead Fermentation}

The stingless bee honey used in this experiment (Table 2) was obtained from a local beekeeper in Thailand's southern region. Pereira et al. (2013) and Mendes-Ferreira et al. (2013) described a method of honey-must preparation for fermentation with a selected yeast consortium. The honey was diluted in commercial natural spring water (Table 3) to $37 \%(\mathrm{w} / \mathrm{v}$ ) solution and autoclaved to remove contaminating microbes to produce an alcoholic beverage with approximately $11 \%(\mathrm{v} / \mathrm{v})$ ethanol. The fermentation took place in a $250 \mathrm{~mL}$ glass-bottom filled to $70 \%$ of its total volume with no additions and shaken at $30^{\circ} \mathrm{C}$. Determination of carbon dioxide $\left(\mathrm{CO}_{2}\right)$ production was used to monitor the fermentation processes.

\subsection{Specific Gravity}

A sample was taken from the honey mead at the end of the ethanol fermentation. A densitometer was used to determine the specific gravity (SG). The wine's percentage alcohol content (\%), calories (calories/oz), residue sugar (\%), apparent fermentation degree (\%), and fermentative capacity $(\mathrm{g} / \mathrm{L})$ were calculated as follows (Balogu and Towobola, 2017):

Percent alcohol by volume (\% ABV)

$=[($ initial $S G-$ final SG) $/ 7.36] \times 1000$

Residual sugar (\% RS)

$=231.3[1-(1 /$ final SG $)]$

Apparent fermentation degree (\% AFD)

$=[($ initial SG - final SG) $/$ initial SG $] \times 100$

Fermentative capacity $(\mathrm{g} / \mathrm{L})$

= initial RS - final RS

\subsection{Proximate Compositional and Physiochemical Analysis}

The Association of Official Chemists (AOAC) methods were used to establish the proximate nutritional composi-
Table 2 Characteristics of raw stingless bee honey used in this experiment.

\begin{tabular}{|l|c|c|}
\hline Characteristics & Value in raw honey & Unit \\
\hline Moisture content & $17.10 \pm 0.03$ & $\%$ \\
\hline Ash & $0.33 \pm 0.10$ & $\%$ \\
\hline Crude carbohydrate content & $83.00 \pm 0.02$ & $\%$ \\
\hline Sugar content & $82.73 \pm 0.01$ & $\%$ \\
\hline Crude protein content & ND & $\%$ \\
\hline Crude fibre content & ND & $\%$ \\
\hline Crude fat content & ND & $\%$ \\
\hline pH & $4.10 \pm 0.02$ & - \\
\hline
\end{tabular}

$N D=$ not determined

Table 3 Characteristics of commercial mineral water used in this experiment.

\begin{tabular}{|l|c|c|}
\hline Characteristics & Value in mineral water & Unit \\
\hline Silica & 45.50 & $\mathrm{mg} / \mathrm{L}$ \\
\hline Calcium & 57.00 & $\mathrm{mg} / \mathrm{L}$ \\
\hline Potassium & 1.50 & $\mathrm{mg} / \mathrm{L}$ \\
\hline Magnesium & 6.50 & $\mathrm{mg} / \mathrm{L}$ \\
\hline Bi-carbonate & 220.00 & $\mathrm{mg} / \mathrm{L}$ \\
\hline Chloride & 1.00 & $\mathrm{mg} / \mathrm{L}$ \\
\hline Fluoride & 0.39 & $\mathrm{mg} / \mathrm{L}$ \\
\hline Sulphate & 4.00 & $\mathrm{mg} / \mathrm{L}$ \\
\hline Sodium & 4.00 & $\mathrm{mg} / \mathrm{L}$ \\
\hline $\mathrm{pH}$ & & - \\
\hline
\end{tabular}

tions such as moisture content (\%), crude protein content $(\%)$, crude fibre (\%), crude fat (\%), and total carbohydrate (\%). The physicochemical parameters such as titratable acidity, volatile acidity, and $\mathrm{pH}$ were determined using the method described by Balogu et al. (2017). Briefly, the total titratable acidity (TTA) was measured by titrating $10 \mathrm{~mL}$ of a sample with $0.1 \mathrm{M} \mathrm{NaOH}$ ( $4 \mathrm{~g}$ of $\mathrm{NaOH}$ in $1,000 \mathrm{~mL}$ of distilled water) until a neutral $\mathrm{pH}$ was reached. The TTA and volatile acidity (VA) were calculated as follows:

TTA $(\mathrm{g} / \mathrm{L})=7.5 \times 0.1 \times$ volume of $\mathrm{NaOH}$

VA $(\mathrm{g} / \mathrm{L})=6 \times 0.1 \times$ volume of $\mathrm{NaOH}$

The acetic acid content $(\mathrm{g} / \mathrm{L})$ was determined using the AOAC method, which involved mixing $2 \mathrm{~mL}$ of a sample with $25 \mathrm{~mL}$ of distilled water and titrating with $0.1 \mathrm{M} \mathrm{NaOH}$. As an indicator, a 1\% (w/v) phenolphthalein solution $(0.01 \mathrm{~g}$ of phenolphthalein in $10 \mathrm{~g}$ of absolute ethanol) was used. The acetic acid concentration (\%) was calculated as follows:

Acetic acid concentration $(\%)=$

(volume of $\mathrm{NaOH} \times 0.1 \times 6,000$ ) / 2,000 
Table 4 An overview of sources of ethanol tolerant yeasts

\begin{tabular}{|l|c|c|}
\hline Source & Yeast & Reference \\
\hline Orchard soil & Saccharomyces sp. Orc6 & Moneke et al., 2008 \\
\hline Molasses and Cashew apple & S. cerevisiae & Priya et al., 2011 \\
\hline Winery soil & S. cerevisiae ATKU132 & Thammasittirong et al., 2012 \\
\hline Wine & S. cerevisiae & Thammasittirong et al., 2013 \\
\hline Soil & S. cerevisiae UVNR56 & This study \\
\hline Pineapple peel & Yeast consortium PP02 and PP03 & \\
\hline
\end{tabular}

\section{Results and Discussion}

\subsection{Selection of Ethanol Tolerant Consortium}

Four ethanol-tolerant yeast strains were isolated from the drainage area of a winery in Nakhon Pathom, Thailand, using an enrichment technique in a liquid medium containing 10\% (v/v) ethanol (Thammasittirong et al., 2012). Two ethanol tolerant yeast consortia, designated as PP02 and PP03, were achieved from pineapple peels, while no ethanol tolerant yeast was gained from traditional culture starter balls when they were enriched in a liquid medium containing $5 \%(\mathrm{v} / \mathrm{v})$ ethanol. Table 4 shows the source of ethanol tolerant yeast.

\subsection{Determination of Invertase Activity}

The glycoprotein invertase, also known as $\beta$-fructofurannosidase (E.C. 3.2.1.26), cleaves the terminal non-reducing $\beta$-fructofurannoside residues. It is found in a wide range of organisms, including plants and microorganisms like S. cerevisiae, Candida utilis, and Aspergillus niger (Kulshrestha et al., 2013). Figure 1 depicts the invertase activity of PP02, PP03, and the control (S. cerevisiae Davis904) during cultivation in liquid medium containing sucrose as a sole carbon source at $30{ }^{\circ} \mathrm{C}, \mathrm{pH}$ 7. The results show that the maximal invertase activity of PP03 is $75.13 \pm 9.16 \mathrm{U} / \mathrm{mL}$, which is $20.05 \%$ and $24.57 \%$ more than the control commercial strain $(60.07 \pm 3.23 \mathrm{U} / \mathrm{mL})$ and the PP02 $(56.67 \pm 4.06 \mathrm{U} / \mathrm{mL})$, respectively. Furthermore, the time course of invertase activity of the PP02 consortium is very similar to the course of the control strain, while the maximum determined value of PP02 is even slightly higher than at the control strain. The invertase activity highly depends on cultivation conditions such as sucrose concentration, $\mathrm{N}$-source, $\mathrm{pH}$, aeration, type of cultivation (submerged $\times$ surface; batch $\times$ fed-batch $\times$ continu- ous) etc. (Vitolo et al., 1995). That is why it is difficult to compare the obtained invertase activity with literature data. The reported data of several papers dealing with invertase activity of $S$. cerevisiae under similar conditions as in this study indicate that there is a number of other (genetic) aspects influencing invertase activity. The studies were conducted at the media composed of sucrose $1-4 \%$, yeast extract $0.2-0.3 \%$ and peptone $0.25-0.5 \%$, pH 5-7, temperature $22-36{ }^{\circ} \mathrm{C}$ and the incubation time $48-72 \mathrm{hrs}$. Haq et al. (2005) informed how cultivation conditions can influence the invertase activity of five wild strains of $S$. cerevisiae isolated from date palm fruit (Phoenix dactylifera) and found invertase activity ranging in 42.02-59.61 $\mathrm{U} / \mathrm{mL}$ depending on the set cultivation parameters. Ali et al. (2016) detected that the wild-type of S. cerevisiae isolated from soil reached only $17 \mathrm{U} / \mathrm{mL}$ but its chemically induced mutant reached between 23-74 $\mathrm{U} / \mathrm{mL}$ of invertase activity again depending on cultivation parameters. On the other hand, Shatif et al. (2002) studied the effect of mineral nutrients on the invertase activity of the strain $S$. cerevisiae GCB-K but the maximal value was only $12.68 \mathrm{U} / \mathrm{mL}$.

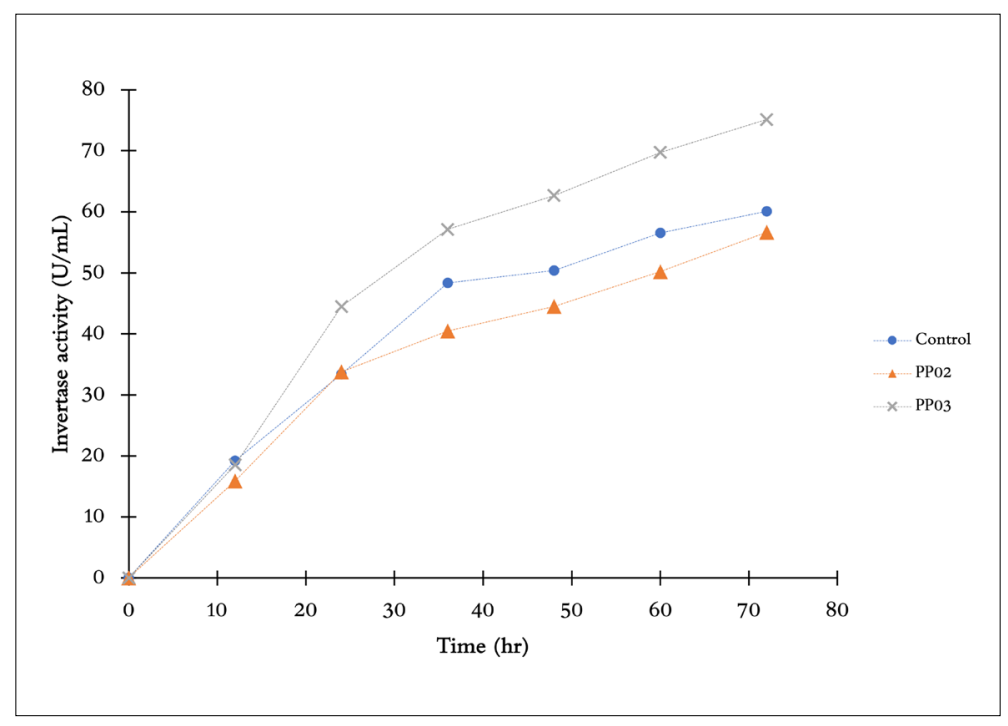

Figure 1 Invertase activity of selected consortium and control (S. cerevisiae Davis904) when they were incubated at $30^{\circ} \mathrm{C}$ for 3 days in a liquid medium. 
Kumar and Kesavapillai (2012) demonstrated that $S$. cerevisiae isolated from ethanol fermentation slurry can produce even $107.5 \mathrm{U} / \mathrm{mL}$ extracellular invertase activity in $72 \mathrm{hrs}$ via solid substrate fermentation at $40{ }^{\circ} \mathrm{C}$ and $\mathrm{pH} 5$. This extreme value exceeds the invertase activity of our consortium PP03 by $30.11 \%$. However, that experiment was conducted under completely different culture conditions which in our case have not been tested.

\subsection{Determination of Ethanol Tolerance}

The ethanol tolerant consortia PP02 and PP03, as well as the control strain, were inoculated into the media containing dif-

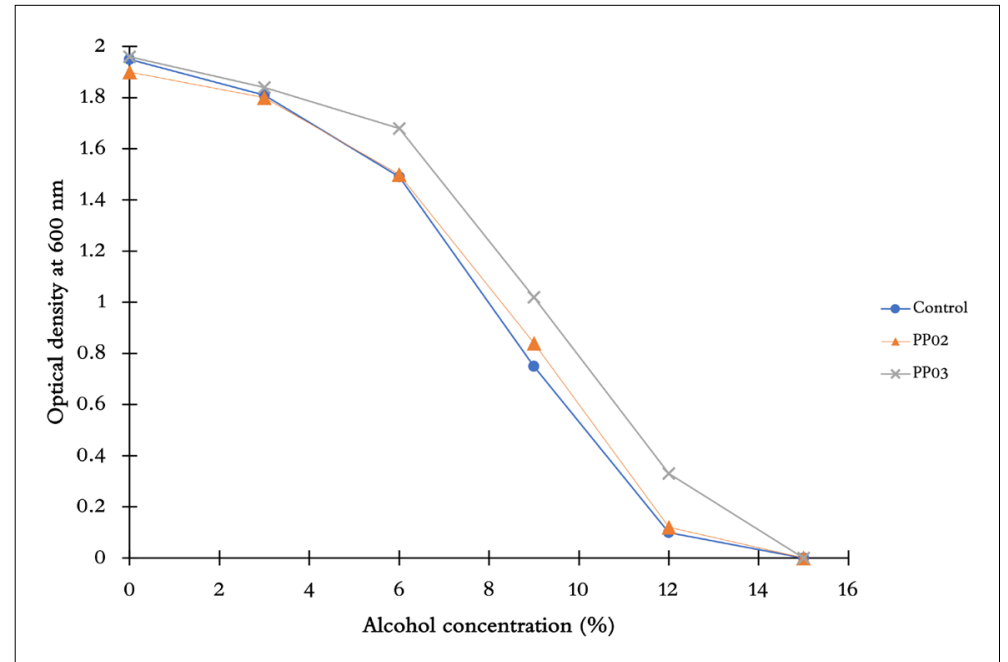

Figure 2 Ethanol tolerance level of selected consortium and control (S. cerevisiae Davis904). ferent ethanol concentration ranging be tween $0-15 \%$. After 3 days of incubation without shaking, the tolerance levels of PP02 and the control of up to $6 \%$ of ethanol were determined by tracking the growth potential at $\mathrm{OD}_{600}$. The strain PP03 showed substantially better tolerance to ethanol up to the level of $12 \%$ (Figure 2). It is well known that many representatives of $S$. cerevisiae are highly tolerant to ethanol accumulated in their environment (Chi and Arneborg, 2000). However, the level of ethanol tolerance greatly varies among individual strains as shown in Table 5 depending on genetics and the ability to adapt to increasing ethanol concentration in their environment. Other factors such as temperature and osmotic pressure also interfere with the yeast resistance to ethanol stress (da Silva et al., 2013). That is why winemakers and researcher can describe low, high and very high ethanol tolerant yeasts. In addition to the biologically distinct abilities to tolerate certain levels of ethanol, it is necessary to point out the issue of the lack of precise ethanol tolerance definition. Usually, viability or surviving ability of the yeast cells, that are exposed to different concentrations of ethanol, is used for comparative studies. The most similar case to our study is the research on nine yeast isolates from sugarcane juice from a Brazilian distillery. The authors found that some yeasts showed fermentative activity between 6 and $8 \%$ of ethanol at $30{ }^{\circ} \mathrm{C}$ and that at $10 \%$ of ethanol no fermentation was detected at all (da Silva et al., 2013). These findings closely correspond to our results for PP02 and the control strain. Moreover, the same authors detected one more resistant strain among the wild strains, which was able to ferment at the ethanol contents of 10 and $12 \%$ at $30{ }^{\circ} \mathrm{C}$ similarly to our PP03 strain. Also Tikka et al. (2013) reported that seven strains of $S$. cerevisiae obtained from different fruit displayed the ethanol tolerance levels between 7-12\%.

However, some Saccharomyces strains are able to produce extremely high concentrations of ethanol and thus they are commonly considered to be extensively ethanol tolerant. In traditional practice of fermentation beverages,

Table 5 Comparison of ethanol tolerance level of yeasts in this study with others.

\begin{tabular}{|l|c|c|}
\hline Yeast strain / Consortium & Tolerance level (\%) & Reference \\
\hline H. uvarum & 25 & Osho et al., 2004 2005 \\
\hline Saccharomyces sp. & 9 & Stanley et al., 2010 \\
\hline S. cerevisiae YEPD & 7 & Park et al., 2012 \\
\hline S. cerevisiae SH631 & 8 & Yamaoka et al., 2014 \\
\hline mixed culture of S. cerevisiae and K. lactis & 20 & Ganucci et al., 2018 \\
\hline S. cerevisiae & 7 & Villarreal et al., 2021 \\
\hline Lachancea cidri & 8 & This study \\
\hline S. cerevisiae Davis 904 (Control) & 6 & This study \\
\hline PP02 & 6 & This study \\
\hline PP03 & 12 & \\
\hline
\end{tabular}


the following order relating to ethanol production/tolerance is accepted: sake yeasts $>$ wine yeasts $>$ distillers' yeasts $>$ brewers' yeasts (Casey and Ingledew, 1986). The examples of extreme tolerance/resistance to ethanol levels can be the study of Pina et al. (2004). The research team showed that Hanseniaspora uvarum isolated from grape must used for Port wine production can survive even at $25 \%$ ethanol concentration. Moreover, the work of Yamaoka et al. (2014) indicated that the mixed culture of S. cerevisiae and Kluyveromyces lactis can grow at $20 \%$ ethanol concentration when they were incubated for 8-15 days.

\subsection{Honey Mead Fermentation}

The PP03 yeast consortium, which displayed a better tolerance to ethanol, was used as a starter culture for honey mead fermentation $\left(1.0 \times 10^{8} \mathrm{cell} / \mathrm{mL}\right)$. The fermentation process of stingless bee honey diluted with mineral water was carried out at $30{ }^{\circ} \mathrm{C}$ for 21 days without shaking. Microbial activity was detected by monitoring $\mathrm{CO}_{2}$ production. After 21 days of incubation, the enological properties of honey mead were determined. The results showed the TTA of $12.85 \mathrm{~g} / \mathrm{L}$, VA of $10.28 \mathrm{~g} / \mathrm{L}$, acetic acid concentration of $5.14 \%$, ABV of $9.90 \%$, RS of $34.41 \%$, AFD of $6.71 \%$, and fermentative capacity of $190.59 \mathrm{~g} / \mathrm{L}$ were achieved. This study yielded a slightly higher TTA than the previous study by Pereira et al. (2019), which yielded $5.87 \mathrm{~g} / \mathrm{L}$ when the mead was fermented by a single strain of $S$. cerevisiae. However, our work still provides the same level of TTA as the study, which produced mead by $S$. cerevisiae and honey must was prepared from honey and coconut water (Balogu and Towobola, 2017).

Table 6 presents basic nutritional and physiochemical parameters.

Pereira et al. (2013) previously used $S$. cerevisiae $\left(1.0 \times 10^{8} \mathrm{cell} / \mathrm{mL}\right)$ for mead fermentation. The ABV was $10.03 \pm 0.38 \%$ when fermented at $22{ }^{\circ} \mathrm{C}$ with mild shaking (120 rpm/min) supplemented with $5 \mathrm{~g} / \mathrm{L}$ potassium tartrate, and $\mathrm{pH}$ adjusted with malic acid. On the other hand, the low-density yeast cell with $1.0 \times 10^{6}$ cell $/ \mathrm{mL}$ has been used for mead fermentation. The results show that the optimal range of microbial growth was 30 days at $25{ }^{\circ} \mathrm{C}$ with the addition of $5 \mathrm{~mL}$ of $0.02 \%(\mathrm{w} / \mathrm{v}$ ) citric acid (Balogu and Towobola, 2017).

\section{Conclusion}

The PP03 yeast consortium was isolated from wild pineapple peel collected from the Phang Nga province, Thailand using an enrichment technique. This consortium had a higher invertase activity of $75.13 \pm 9.16 \mathrm{U} / \mathrm{mL}$ and ethanol tolerance of up to $12 \% \mathrm{v} / \mathrm{v}$ than the other isolate of PP02 and commercial control strain of $S$. cerevisiae. We
Table 6 Nutritional and physiochemical properties of honey mead from Thai stingless bee honey using ethanol tolerant yeast consortium PP03

\begin{tabular}{|l|c|c|}
\hline Parameters & Honey mead & Unit \\
\hline Total carbohydrate & 6.85 & $\%$ \\
\hline Moisture content & 93.12 & $\%$ \\
\hline Ash & 0.03 & $\%$ \\
\hline Crude fat content & ND & $\%$ \\
\hline Crude fibre content & ND & $\%$ \\
\hline Total protein content & ND & $\%$ \\
\hline pH & 4.10 & - \\
\hline
\end{tabular}

demonstrated a promising ability of the PP03 consortium to grow under ethanol stress conditions. The isolate was also used to produce the first experimental honey mead from stingless bee honey. However, this is a preliminary research that needs to be complemented by further microbiological and technological data.

\section{Acknowledgements}

We would like to thank Keawmanee, N., Chaijak, S. and Kongnum, N. for their assistance in sample collection in this experiment and also to thank the Department of Biology, Faculty of Science, Thaksin University for their laboratory support.

\section{References}

Anderson, M. J., Barker, S. L., Boone, C., Measday, V. (2012). Identification of RCN1 and RSA3 as ethanol-tolerant Saccharomyces cerevisiae using a high copy barcoded library. FEMS Yeast Research, 12(1), 48-60. https://doi.org/10.1111/j.1567-1364.2011.00762.x

Ali, S., Aslam, A., Hayyat, M. U. (2016). Double mutation of Saccharomyces cerevisiae for enhanced $\beta$-D-fructofuranosidase fructohydrolase productivity and application of growth kinetics for parametric significance analysis. Industrial Microbiology, 47, 136-142. https://doi. org/10.1016/j.bjm.2015.11.024

Balogu, T. V., Towobola, O. (2017). Production and quality analysis of wine from honey and coconut milk blend using Saccharomyces cerevisiae. Fermentation, 3(16), 1-9. https://doi.org/10.3390/fermentation3020016.

Casey, G. P., Ingledew, W. M. M. (1986). Ethanol tolerance in yeasts. CRC Critical Review in Microbiology, 13(3), 219-280. https://doi. org/10.3109/10408418609108739

Chang, K. J., Thach, M. W. L., Olsen, J. (2016). Wine and health perceptions: exploring the impact of gender, age and ethnicity on consumer perceptions of wine and health. Wine Economics and Policy, 5(2), 105-113. https://doi.org/10.1016/j.wep.2016.09.001

Chi, Z., Arneborg, N. (2000). Saccharomyces cerevisiae strains with different degrees of ethanol tolerance exhibit different adaptive responses to produced ethanol. Journal of Industrial Microbiology and Biotechnology, 24, 75-78.

Cooray, S. T., Lee, J. J. L., Chen, W. N. (2017). Evaluation of brewers' spent grain as a novel media for yeast growth. AMB Express, 7, 117. https:// doi.org/10.1186/s13568-017-0414-1 
Da Silva, R. O., Batistote, M., Cereda, M. P. (2013). Alcoholic fermentation by the wild yeasts under thermal, osmotic and ethanol stress. Brazilian Archives of Biology and Technology, 56(2), 161-169. https://doi. org/10.1590/S1516-89132013000200001

De Groot, A. P. (1953). Protein and amino acid requirement of the honey bee Apis mellifera. Physiologia Comparata et d' Ecogia, 3, 195-285.

De Simon, B. F., Martinez, J., Sanz, M., Cadahia, E., Esteruelas, E., Esteruelas, E., Munoz, A. M. (2014). Volatile compounds and sensorial characterization of red wine aged in cherry, chestnut, false acacia, ash and oak wood barrels. Food Chemistry, 147, 346-356. https://doi. org/10.1016/j.foodchem.2013.09.158

Edelhauser, M., Bergner, K. G. (1987). Proteine Des Bienenhonigs. Lebensmittelunters. Forsch.

Flor, P. Q., Hayashida, S. (1983). Saccharomyces uvarum inulyticus var. nov., a new high-concentration ethanol tolerant yeast from rice wine. European Journal of Applied Microbiology and Biotechnology, 18, 148-152. https://doi.org/10.1007/BF00498036

Ganucci, D., Guerrini, S., Mangani, S., Vincenzini, M., Granchi, L. (2018). Quantifying the effects of ethanol and temperature in the fitness advantage of predominat Saccharomyces cerevisiae strains occurring in spontaneous wine fermentations. Frontiers in Microbiology, 9, 1563. https://doi.org/10.3389/fmicb.2018.01563.

Ghasemi, Y., Mohkam, M., Ghasemi, A., Rasoul-Amini, S. (2014). Experimental design of medium optimization for invertase production by Pichia sp. Journal of Food Science and Technology, 51, 267-275. https://doi. org./ 10.1007/s13197-011-0494-X

Guan, D., Li, Y., Shiroma, R., Ike, M., Tokuyasu, K. (2013). Sequential incubation of Candida shehatae and ethanol-tolerant yeast cells for efficient ethanol production from a mixture of glucose, xylose and cellobiose. Bioresource Technology, 132, 419-422. https://doi.org/10.1016/j. biortech.2012.12.040

Gupta, J. K., Sharma, R. (2009). Production technology and quality characteristics of mead and fruit-honey wines: A review. Natural Product Radiance, 8(4), 345-355.

Haq, I. U., Baig, M. A., Ali, S. (2005). Effect of cultivation condition on invertase production by hyperproducing Saccharomyces cerevisiae isolates. World Journal of Microbiology \& Biotechnology, 21, 487-492. https:/ doi.org/10.1007/s11274-004-2612-7.

Hornsey, I. S. (2007). A history of beer and brewing. Royal Society of Chemistry, Cambridge, pp. 760. ISBN 0854046305

Jame, C. N. (2004). Recruitment communication in stingless bees (Hymenoptera, Apidae, Meliponini). Apidologie, 35, 159-182. https://doi. org/10.1051/apido:2004007

Jimnez, J., Benitez, T. (1986). Characterization of wine yeasts for ethanol production. Applied Microbiology and Biotechnology, 25, 150-154. https://doi.org/10.1007/BF01982839

Kulshrestha, S., Tyagi, P., Sindhi, V., Yadavilli, S. (2013). Invertase and its applications - A brief review. Journal of Pharmacy Research, 7(9), 792-797. https://doi.org/10.1016/j.jopr.2013.07.014

Kumar, R., Kesavapillai, B. (2012). Stimulation of extracellular production from spent yeast when sugarcane pressmud used as substrate through solid state fermentation. SpringerPlus, 1(1), 81. https://doi. org/10.1186/2193-1801-1-81

Lim, D. C. C., Bakar, M. F. A., Majid, M. (2019). Nutritional composition of stingless bee honey from different botanical origins. Earth and Environmental Science, 269, 012025. https://doi.org/10.1088/1755$1315 / 269 / 1 / 012025$

Makwana, M., Hati, S. (2019). Fermented Beverages. Woodhead Publishing, Cambridge. ISBN: 9780128152713

Mendes-Ferreira, A., Cosme, F., Barbosa, C., Falco, V., Ines, A., Mendes-Faia, A. (2010). Optimization of honey-must preparation and alcoholic fermentation by Saccharomyces cerevisiae for mead production. In- ternational Journal of Food Microbiology, 144, 193-198. https://doi. org/10.1016/j.ijfoodmicro.2010.09.016

Moneke, A. N., Okolo, B. N., Nweke, A. I., Ezeogu, L. I., Ire, F. S. (2008). Selection and characterisation of high ethanol tolerant Saccharomyces yeasts from orchard soil. African Journal of Biotechnology, 7(24), 4567-4575.

Nguyen, H. P., Le, H. D., Le, V. V. M. (2015). Effect of ethanol stress on fermentation performance of Saccharomyces cerevisiae cells immobilized on nypa fruticans leaf sheath pieces. Food Technology and Biotechnology, 53(1), 96-101. https://doi.org/10.17113/ftb.53.01.15.3617

Osho, A. (2005). Ethanol and sugar tolerance of wine yeasts is fermenting cashew apple juice. African Journal of Biotechnology, 4(7), 660-662.

Park, A. H., Sugiyama, M., Harashima, S., Kim, Y.H. (2012). Creation of an ethanol-tolerant yeast strain by genome reconstruction based chromosome splitting technology. Journal of Microbiology and biotechnology, 22(2), 184-189. http://dx.doi.org/10.4014/jmb.1109.09046

Pereira, A. P., Mendes-Ferreira, A., Oliveira, J. M., Estevinho, L. M., MendesFaia, A. (2013). High-cell-density fermentation of Saccharomyces cerevisiae for the optimization of mead production. Food Microbiology, 33, 114-123. https://doi.org/10.1016/j.fm.2012.09.006

Perreira, A. P., Mendes-Ferreira, A., Dias, L. G., Oliveira, J. M., Estevinho, L. M., Mendes-Faia, A. (2019). Volatile composition and sensory properties of mead. Microorganisms. 7, 1-16. https://doi.org/10.3390/ microorganisms 7100404.

Pina, C., Santos, C., Couto, J. A., Hogg, T. (2004). Ethanol tolerance of five non-Saccharomyces wine yeasts in comparison with s strain of Saccharomyces cerevisiae - influence of different culture conditions. Food Microbiology, 21, 439-447.

Priya, V. P. A., Anutha, S., Mangalam, H. (2011). Isolation, characterization of ethanol tolerant yeast. Journal of Pure and Applied Microbiology. 5(1), 313-316.

Sawatthum, A., Vaithanomsat, P., Tadakittisarn, S. (2009). Comparitive composition of honey from thai stingless bee and european honey bee. KUCONF, 52, 4271020.

Se, K. W., Ibrahim, R. K. R., Wahab, R. A., Ghoshal, S. K. (2018). Accurate evaluation of sugar contents in stingless bee (Heterotrigona itama) honey using a swift scheme. Journal of Food Composition and Analysis, 66, 46-54. https://doi.org/10.1016/j.jfca.2017.12.002

Shatif, K., Ali, S., Haq, I. U. (2002). Effect of different mineral nutrients on invertase production by sachcaromyces cerevisiae GCB-K5. Biotechnology 1(1), 40-44. https://doi.org/10.3923/biotech.2002.40.44

Shiby, V. K., Misha, H. N. (2013). Fermented milks and milk products as functional foods - a review. Critical Reviews in Food Science and Nutrition, 53(5), 482-496. https://doi.org/10.1080/10408398.2010.547398

Stanley, D., Fraser, S., Chambers, P. J., Rogers, P., Stanley, G. A. (2010). Generation and characterization of stable ethanol-tolerant mutants of Saccharomyces cerevisiae. Journal of Industrial Microbiology and Biotechnology, 37(2), 139-149. https://doi.org/10.1007/s10295009-0655-3

Sumby, K. M., Betteridge, A. L., Jiranek, V. (2019). Ethanol-tolerant lactic acid bacteria strains as a basis for efficient malolactic fermentation in wine: evaluation of experimentally evolved lactic acid bacteria and winery isolates. Australian Journal of Grape and Wine Research, 25(4), 404-413. https://doi.org/10.1111/ajgw.12410

Suntiparapop, K., Prapaipong, P., Chantawannakul, P. (2011). Chemical And Biological Properties Of Honey From Thai Stingless Bee (Tetragonula leaviceps). Journal of Apicultural Research, 51(1), 45-52. https: //doi. org/10.3896/IBRA.1.51.1.06

Tikka, C., Osuru, H. P., Atluri, N., Raghavulu, P. C. V., Yellapu, N. K., Mannur, I. S., Prasad, U. V., Aluru, S., Varma, N. K., Bhaskar, M. (2013). Isolation and characterization of ethanol tolerant yeast strains. Bioinformation, 9(8), 421-425. https://doi.org/10.6026/97320630009421 
Thmmasittirong, S. N. R., Chamduang, Y., Phonrod, U., Sriroth, K. (2012). Ethanol production potential of ethanol-tolerant Saccharomyces and non-Saccharomyces yeast. Polish Journal of Microbiology, 61(3), 219-221. https://doi.org/10.33073/pjm-2012-029

Thmmasittirong, S. N. R., Thirasaktana, T., Thammasittirong, A., Srisodsuk, M. (2013). Improvement of ethanol production by ethanol tolerant Saccharomyces cerevisiae UVNR56. SpringerPlus, 2, 1-5. https://doi. org/10.1186/2193-1801-2-583

Tyokusa, A. G., Owuama, C. I. (2018). Indigenous ethanol tolerant Saccharomyces cerevisiae isolates for Mangifera indica and Ananas comosus wines production. International Journal of Science, Environment and Technology, 7(2), 435-450.

Villarreal, P., Quintrel, P. A., Olivares-Munoz, S., Ruiz, J. J., Nespolo, R. F., Cubillos, F. A. (2021). Identification of new ethanol-tolerant yeast strains with fermentation potential from central Patagonia. Yeast, https:// doi.org/10.1002/yea.3662

Vitolo, M., Duranti, M. A., Pellegrim, M. B. (1995). Effect of pH, aeration and sucrose feeding on the invertase activity of intact $S$. cerevisiae cells grown in sugarcane blackstrap molasses. Journal of Industrial Microbiology, 15(2), 75-79. https://doi.org/10.1007/BF01569803

Walker, G., Stewart, G. (2016). Saccharomyces cerevisiae in the production of fermented beverages. Beverages, 2(4), 30. https://doi. org/10.3390/beverages2040030

Yamaoka, C., Kurita, O., Kubo, T. (2014). Improved ethanol tolerance of Saccharomyces cerevisiae in mixed culture with Kluyveromyces lactis on high-sugar fermentation. Microbiological research, 169, 907-914. http://dx.doi.org/10.1016/j.micres.2014.04.007 